6-3-2016

\title{
Guest Editors' Introduction: Genocide Studies, Colonization, and Indigenous Peoples
}

David B. MacDonald

Tricia Logan

Royal Holloway University of London

Follow this and additional works at: https://digitalcommons.usf.edu/gsp

\section{Recommended Citation}

MacDonald, David B. and Logan, Tricia (2016) "Guest Editors' Introduction: Genocide Studies, Colonization, and Indigenous Peoples," Genocide Studies and Prevention: An International Journal: Vol. 10: Iss. 1: 2-4.

DOI:

http://dx.doi.org/10.5038/1911-9933.10.1.1423

Available at: https://digitalcommons.usf.edu/gsp/vol10/iss1/4

This Editorial is brought to you for free and open access by the Open Access Journals at Digital Commons @ University of South Florida. It has been accepted for inclusion in Genocide Studies and Prevention: An International Journal by an authorized editor of Digital Commons @ University of South Florida. For more information, please contact digitalcommons@usf.edu. 


\section{Guest Editors' Introduction: Genocide Studies, Colonization, and Indigenous Peoples}

As guest editors we are pleased to introduce the symposium on Indigenous genocide in Issue 10.1 of Genocide Studies and Prevention: An International Journal, featuring three articles on various aspects of this important topic. While the focus is primarily on selected Indigenous peoples of what are now the Americas, these articles also have comparative dimensions, suggesting a broader theoretical and practical applicability.

Last year, the full special issue of "Time, Movement and Space: Genocide Studies and Indigenous Peoples" (Issue 9.2) helped contribute to the growing dialogue and turn discussion to an increasingly decolonized vision of genocide studies. These two issues of the Genocide Studies and Prevention include and also transcend the discussion of definitional debates. The range of topics included in these special issues help to demonstrate how seemingly diverse cases of genocide compliment a unified narrative of how colonialism/colonization disintegrated Indigenous lives worldwide.

Since our previous special issue in 2015, the context of Indigenous-settler relations has somewhat changed in Canada. On 15 December 2015, Canada's Truth and Reconciliation Commission held its final event in Ottawa, a small ceremony in which a six volume report totaling over 2 million words was released to the media and the general public. The report was divided as follows: The History, Part 1 - Origins to 1939; The History, Part 2 - 1939 to 2000; The Inuit and Northern Experience; The Métis Experience; Missing Children and Unmarked Burials; The Legacy; and Reconciliation.

The primary concern of the TRC was promoting reconciliation according to 94 recommendations, which included a range of measures from increased funding for Indigenous programing for the Canadian Broadcasting Corporation to the adoption into domestic law of the UN Declaration on the Rights of Indigenous Peoples, as well as a national monitoring body to oversee and report back annually on the implementation of the TRC recommendations. The TRC commissioners posit that as the Indian Residential Schools system lasted for seven generations, so too might it take seven generations before reconciliation can be achieved in Canada. They have set an ambitious agenda, based on thousands of conservations with Survivors and many others, and their recommendations also build on the 1996 Report of the Royal Commission on Aboriginal Peoples.

Another major change took place on 20 October, when the Conservative government of Stephen Harper was decisively toppled by the Liberal Party of Justin Trudeau. Harper's administration was generally perceived as hostile to Indigenous interests, and much of the regime's legislation was designed to reduce the self-determining capacities of First Nations peoples. Indeed, Harper's legislative agenda (such as omnibus Bill C- 45 removing federal protection from most forests and waterways) precipitated the formation of Idle No More in late 2012. Many prominent Harper-era cabinet ministers were not re-elected to Parliament, including Aboriginal Affairs minister Bernard Valcourt, who notably refused to rise or applaud the work of the TRC when they released their summary report in June 2015.

While it is too early to properly gauge the policies of the current Trudeau era, the government has been far more positive (at least rhetorically) in terms of embracing Indigenous rights. For example, former TRC Chief Commissioner Murray Sinclair was appointed as a Senator by the Trudeau government, and Trudeau has more widely consulted with First Nations leaders, and has forged strong relations with the Assembly of First Nations, in particular National Chief Perry Bellegarde.

In May of this year, the government pledged at the Permanent Forum on Indigenous Issues at the United Nations to formally adopt the UNDRIP and incorporate its provisions into domestic law, which will mean harmonizing existing law with the UNDRIP. This ended nine years of Conservative opposition to the Declaration. While Canada was the last of the four western settler states to adopt it (Australia, the United States, and New Zealand all changed their attitudes earlier) it's possible that Canada may adopt the most far-reaching changes to its domestic legislation. ${ }^{1}$

Despite these high profile changes of attitude, problems within Indigenous communities remain serious, such as for example the recent crisis at the First Nation of Attawapiskat, which in early

\footnotetext{
1 "Canada officially adopts UN declaration on rights of Indigenous Peoples" CBC News, May 10, 2016, accessed June 2, 2016, http://www.cbc.ca/news/aboriginal/canada-adopting-implementing-un-rights-declaration-1.3575272.
} 
2016 declared a state of emergency due to a dangerously high suicide rate. While the population of this First Nations is around 2,000 people, over 100 people have killed themselves from September 2015 to April 2016, children as young as 11 years old. Deplorable housing conditions, systemic racism, extremely poverty, and many other issues have been cited as causes. ${ }^{2}$ The federal budget has not gone far enough in terms of correcting the funding shortfalls of previous governments, despite federal government claims to the contrary.

Overall the government appears to be making some progressive change to improve relationships with Indigenous peoples as individuals and as nations. The situation will be more complicated than it currently seems since UNDRIP is not just about honouring existing treaties or forging better relationships with existing First Nations bands as recognized under the federal Indian Act. It is about a renewed relationship, which will also imply honouring Indigenous forms of government and identity which are not fully covered in existing legislation. Metis and nonstatus Indigenous peoples may in particular be strong beneficiaries of this change in direction.

Going into this second special issue, we are somewhat more hopeful about the future direction of Indigenous issues in Canada. Rather than being a laggard internationally, Canada has the potential to play a positive role in promoting UNDRIP, if sufficient political will exists. South of the Canadian border it is unclear what sort of changes will develop after the presidential and Congressional elections this coming November. At the time of writing neither Donald Trump nor Hillary Clinton has been confirmed as the presidential nominee for their respective parties. Neither candidate appears particularly progressive on Indigenous issues, although a Trump presidency would most likely be more retrograde than a Clinton one.

The three articles in this special issue explore various aspects of Indigenous genocide, employing comparative and theoretical perspectives. In her article, "In the Land of the Mountain Gods: Ethnotrauma and Exile Among the Apaches of the American Southwest," M. Grace Hunt Watkinson focuses her attention on the Mescalero and the Chiricahua Apaches of what is now New Mexico. In particular, her work explores how the brutality of colonization, which included vigilante violence and forced removal, created forms of collectively based "ethnotrauma." A key aspect of such ethnotrauma is exile from traditional lands, which can in part be resolved or healed by a renewal of sacred connections to the lands that sustained Indigenous communities over millennia.

Chris Powell develops the concepts of ethnosphere and ethnodiversity to highlight how cultural genocide of Indigenous peoples can best be understood in an increasingly globalizing age. As Powell explains, reflecting in part the work of Wade Davis: "The global ethnosphere is the totality of all living human cultures; ethnodiversity is the degree of cultural diversity in a given social arena." Linguistic and cultural extinction threaten to destroy the potential contributions of many of the world's Indigenous peoples. Building on Lemkin, Powell advances an argument in favour of viewing the loss of ethnodiversity through the lens of genocide. As a more global society evolves, Powell alerts us to some of the dangers it poses, particular for Indigenous peoples.

Finally, Andrew Basso has contributed an article entitled "Towards a Theory of Displacement Atrocities: The Cherokee Trail of Tears, The Herero Genocide and the Pontic Greek Genocide." Here, Basso employs stories of atrocity to focus on three cases of mass displacement. Through these cases, Basso poses a theoretical frame of "displacement atrocities". These cases are also representative of stories that are rarely examined and even more rarely, examined together. Basso's discussion of "indirect killing" through displacement atrocity opens a broader dialogue about long-term, systematic removal of populations through deprivation from food, water, shelter and medicine. This article is placed at an intersection between multiple segments of genocide studies including: displacement atrocities, mass deprivation and long-term, systematic killings.

Constructing a theoretical frame for these cases, Basso outlines how perpetrators use or do not use displacement to remove population. His cases are convincing and diverse but also, each case demonstrates how territory is unjustly claimed through destruction of a group. Between various cases and theories we always need to consider or re-consider how we work with comparative

\footnotetext{
${ }^{2}$ Laurence Mathieu-Léger and Ashifa Kassam, “First Nations community grappling with suicide crisis: 'We're crying out for help"', The Guardian, April 16, 2006, accessed June 2, 2016, http://www.theguardian.com/world/2016/apr/16/ canada-first-nations-suicide-crisis-attawapiskat-history.
} 
genocides. The way that Basso describes and names atrocity is compelling and lends to a discussion on the theories we select when labeling atrocities or genocide. Moreover, when we consider the set of cases selected for this article it reminds us how important it is to keep shifting the way we select cases and continually re-align our view in order to see things from a renewed perspective.

We should also note that this focus on Indigenous genocide has been echoed in the Journal of Genocide Research, where a special issue on Canada and Colonial Genocide was also released last year (Volume 17, Issue 4). As academics promoting a decolonizing turn in genocide studies, we both contributed articles to that issue. David's is entitled "Canada's history wars: indigenous genocide and public memory in the United States, Australia and Canada", and Tricia's is entitled "Settler colonialism in Canada and the Métis." We have been told that this special issue will be published as an edited book sometime within the next year.

Last but not least, our thanks go to the authors, our anonymous peer-reviewers, the GSP editorial board, and of course Mel O'Brien who has worked tirelessly to ensure that this volume was of high quality and made it to press on time. We look forward to working with her and with Genocide Studies and Prevention again in the future.

David B. MacDonald Tricia Logan 